\title{
Metoda tomografii ultradźwiękowej - próba nieniszczącej lokalizacji zbrojenia w elemencie betonowym
}

\author{
Ultrasonic tomography method - non-destructive \\ testing of location reinforcement in the concrete \\ element
}

\section{Streszczenie}

W artykule przedstawiono próbę nieniszczącej lokalizacji zbrojenia w elemencie betonowym z zastosowaniem nowoczesnej nieniszczącej metody badawczej tomografii ultradźwiękowej. Metoda ta nie jest wprawdzie przeznaczona do lokalizacji zbrojenia, ale podczas testów laboratoryjnych otrzymano interesujące wyniki, które zamieszczono w niniejszej pracy. Były to sygnały, jakie otrzymano dla próbki betonowej wykonanej w laboratorium, w której umieszczono zamodelowaną siatkę prętów zbrojeniowych. Analiza uzyskanych rezultatów wykazała, że jest możliwe określenie lokalizacji siatki zbrojeniowej za pomocą metody tomografii ultradźwiękowej, ale do głębokości ok.200 mm elementu betonowego. Zwrócono uwagę, że potrzebe większej liczby takich sygnałów (zobrazowań) wzorcowych, które mogą być przydatne do monitoringu i diagnostyki obiektów wykonanych z betonu.
Abstract

The paper presents the location of the non-destructive test of reinforcement in concrete element with the use of modern non-destructive testing method of ultrasonic tomography. This method is indeed dedicated to the location of the reinforcement, but during laboratory tests gave interesting results, which are presented in this paper. There were signals that were obtained for the samples of concrete performed in the laboratory, which provided a grid of reinforcing bars modeled. Analysis of the results showed that it is possible to determine the location of the reinforcing fabric by the method of ultrasonic tomography, but to a depth of about $200 \mathrm{~mm}$ of the concrete element. It was noted that there is a need to develop more of these signals (imaging) model, which can be useful for monitoring and diagnosis of buildings made of concrete.

\section{Wstęp}

W praktyce budowlanej mamy często do czynienia z sytuacją, w której trzeba zlokalizować zbrojenie w elemencie betonowym. Przykładem takich elementów są wykonane $z$ betonu płyty fundamentowe, słupy, stropy itp. W badaniach tych elementów betonowych warto sto-sować metody nieniszczące umożliwiajace nieinwazyjne wykonanie badań w dowolnej liczbie miejsc.

Dr inż. Krzysztof Schabowicz - Politechnika Wrocławska
Podjęto próbę nieniszczącej lokalizacji zbrojenia $w$ elemencie betonowym $z$ zastosowaniem nowoczesnej nieniszczącej metody badawczej tomografii ultradźwiękowej. Metoda ta nie jest wprawdzie przeznaczona do lokalizacji zbrojenia, ale podczas testów laboratoryjnych otrzymano interesujacce wyniki, które zamieszczono w niniejszej pracy. Warto również zauważyć, że korzystanie z tej metody wymaga jednak dużych umiejętności i doświadczenia od użytkownika, szczególnie na etapie analizy otrzymanych wyników. Pomocne w tym moga być sygnały wzorcowe (zobrazowania wzorcowe). W pracy przedstawiono przykładowe sygnały, jakie otrzymano dla próbki betonowej wykonanej przez autora niniejszej pracy w laboratorium, w której umieszczono zamodelowaną siatkę prętów zbrojeniowych. 


\section{Opis badań}

Do badań zastosowano metodę tomografii ultradźwiękowej, w której wykorzystano aparaturę badawczą przedstawioną na rysunku 1 . Metoda ta jest przydatna zwłaszcza do badania dostępnych jednostronnie elementów z betonu i żelbetu w celu określenia ich grubości, wykrycia pęknięć, obcych wtrąceń, pustek powietrznych i miejsc, które mogą być wypełnione cieczą lub materiałem różniącym się gęstością od otaczającego go betonu, jak również mającego inne fizyczne i mechaniczne właściwości $[1,2,5 \div 7]$. Metoda ta jest oparta na wzbudzeniu fali sprężystej w badanym elemencie. Wzbudnikiem jest wielogłowicowa antena, do której wbudowano kilkadziesiąt niezależnych głowic ultradźwiękowych, służąca również do odbierania i przetwarzania sygnałów ultradźwiękowych [3, 4]. Głowice generują impulsy ultradźwiękowe o częstotliwości $50 \mathrm{kHz}$. Metoda ta została dokładnie opisana w [2].

Badania z wykorzystaniem tomografu ultradźwiękowego (rys. 1) przeprowadzono na betonowej próbce sześciennej o wymiarach 500×1000×1000 mm pokazanej na rysunku 2. Na rysunku tym widać także specjalnie przygotowaną zamodelowaną siatkę zbrojenia, której fotografię pokazano na rysunku 3 wraz z etapami wykonania próbki betonowej. Próbkę tę wykonano $\mathrm{z}$ betonu $\mathrm{C} 25 / 30$ na kruszywie do $8 \mathrm{~mm}$ z betonu towarowego o w/c 0,59. Na próbce pomiarowej zaznaczono siatkę punktów pomiarowych, co pokazano na rysunku 3. W każdym punkcie pomiarowym dokonywano pomiarów prędkości fali ultradźwiękowej i jej rejestracji. Uzyskano w ten sposób obrazy płaskie wnętrza badanego elementu betonowego, w trzech wzajemnie prostopadłych kierunkach pokazanych w postaci trzech zobrazowań B, C i D na rysunku 4.

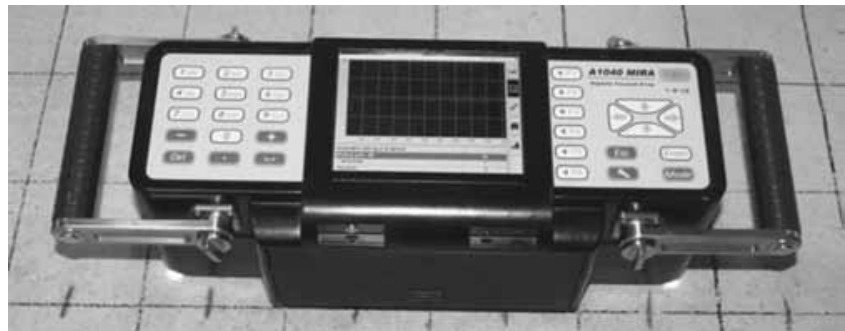

Rys. 1. Aparatura badawcza do metody tomografii ultradźwiękowej Fig. 1. View of test equipment for ultrasonic tomography a)

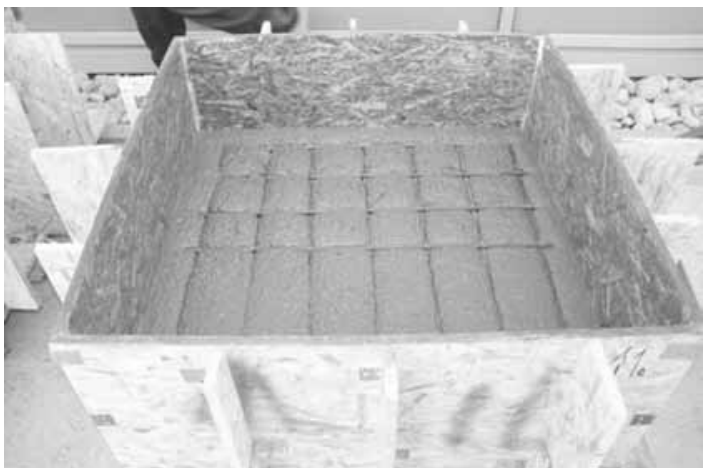

b)

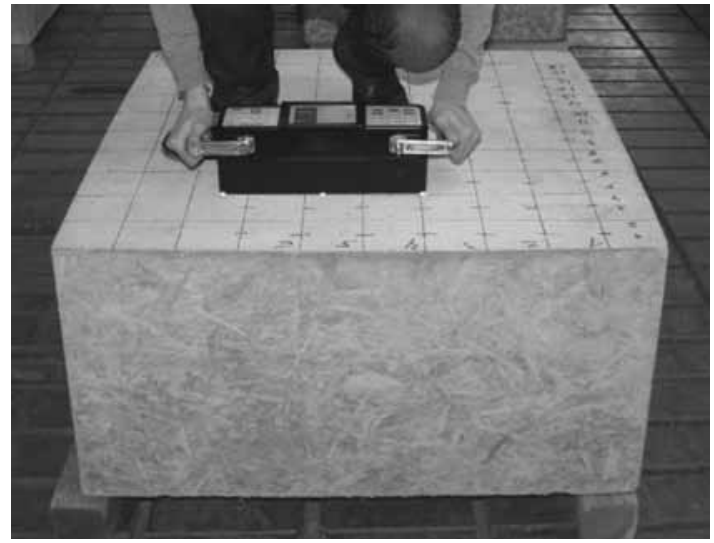

Rys. 3. Etapy wykonania próbki betonowej: a) ułożenie siatki dolnej, b) gotowa próbka z zaznaczonymi miejscami pomiarowymi

Fig. 3. Concrete steps to accomplish the samples: a) the net position of the bottom, b) view of the finished sample with the selected measuring sites

\section{Wyniki badań i ich analiza}

Przykładowe wyniki badań nieniszczących otrzymane za pomocą tomografu ultradźwiękowego, pokazujące zobrazowania typu C, D i B, zamieszczono na rysunku 4 , a na rysunku 5 przedstawiono obraz trójwymiarowy badanego elementu betonowego. Na rysunku 4 strzałkami wskazano zarys górnej siatki zbrojeniowej, którą zlokalizowano za pomocą tomografu ultradźwiękowego; dolnej siatki zbrojeniowej nie zlokalizowano.

Analiza uzyskanych rezultatów wykazała, że jest możliwe określenie lokalizacji zbrojenia za pomocą metody tomografii ultradźwiękowej jedynie do głębokości $200 \mathrm{~mm}$.

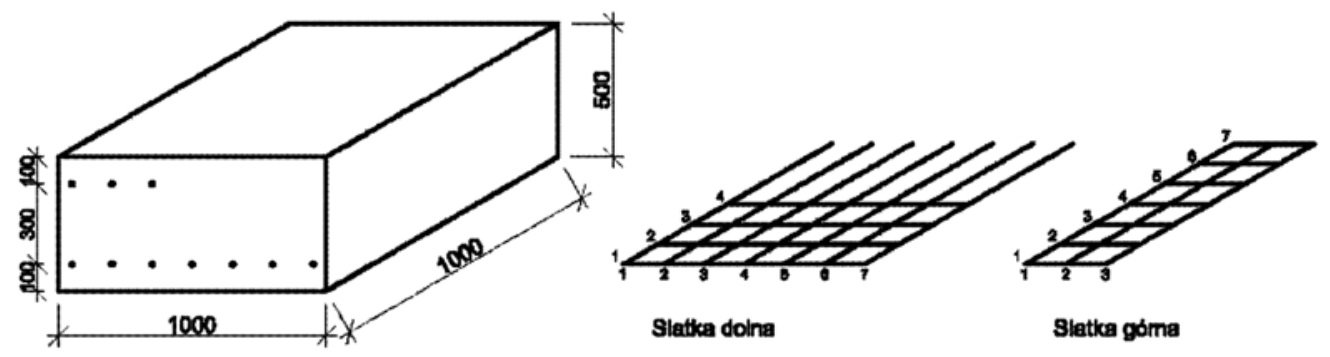

Rys. 2. Schemat próbki do badań z wymiarami zamodelowanej siatki zbrojeniowej

Fig. 2. Diagram of the test sample with the dimensions modeled the mesh 


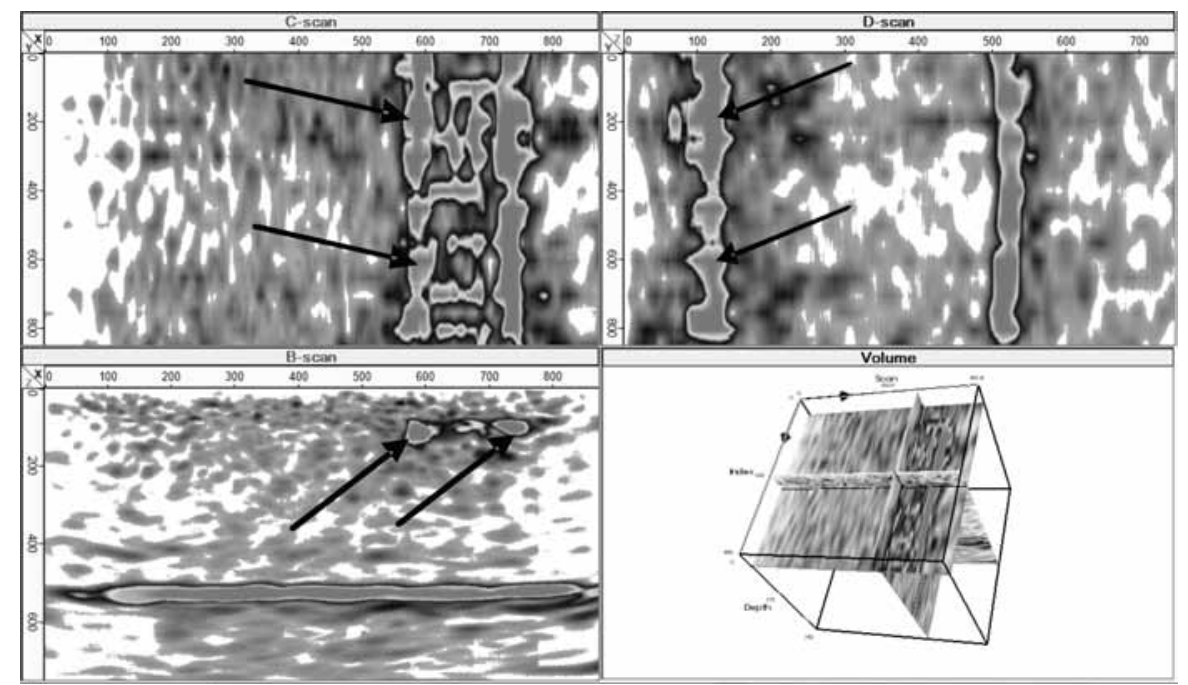

Rys. 4. Wyniki badań dla próbki betonowej. Widoczne zobrazowania C, D i B oraz układ tych trzech wzajemnych prostopadłych przekrojów Fig. 4. The results for a sample of concrete. Visible scans $C, D$ and $B$ and the layout of the three orthogonal cross sections

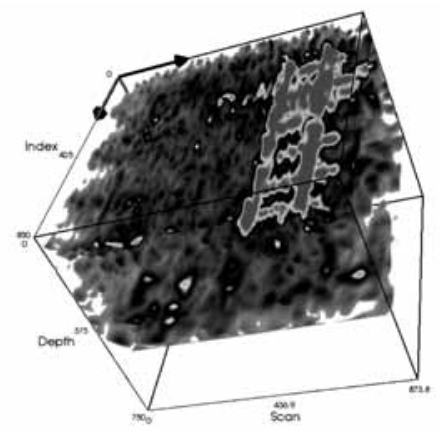

Rys. 5. Wyniki badań dla elementu betonowego uzyskane za pomocą tomografu ultradźwiękowego $w$ formie trójwymiarowego obrazu

Fig. 5. The results obtained for the concrete using ultrasonic tomographer in the form of three-dimensional image

\section{Podsumowanie}

Przedstawiono przykładowe sygnały (zobrazowania), jakie otrzymano w czasie badań nieniszczących dla elementu betonowego wykonanego w laboratorium, w którym umieszczono zamodelowane siatki zbrojeniowe. Badania wykonano metodą tomografii ultradźwiękowej. Metoda ta nie jest powszechnie stosowana i przez to jest mniej znana, dlatego podano krótki opis, przydatny do jej zrozumienia.

W przedstawionych badaniach uzyskane dla próbki betonowej obrazy typu B, C i D pokazują

\section{Literatura}

[1] Bishko A. V., Samokrutov A. A, Shevaldykin V. G.: Ultrasonic echo-pulse tomography of concrete using shear waves lowfrequency phased antenna arrays. e-Journal of Non-destructive Testing \& Ultrasonics, vol. 13, 2008.

[2] Hola J., Schabowicz K., State-of-the-art nondestructive methods for diagnostics testing of building structures - anticipated development trends, Archives of Civil and Mechanical Engineering, 11, 2010.

[3] Kozlov V. N., Samokrutov A. A., Shevaldykin V. G.: Thickness Measurements and Flaw Detection in Concrete Using Ultrasonic Echo Method. J. Nondestructive Testing and Evaluation, 1997, vol. 13, s. 73 - 84 .

zarys górnej siatki zbrojeniowej. Dolnej siatki zbrojeniowej nie udało się zlokalizować.

Analiza uzyskanych wyników wykazała, że jest możliwa lokalizacja ale siatki zbrojeniowej za pomocą metody tomografii ultradźwiękowej, ale do głębokości ok. $200 \mathrm{~mm}$ elementu betonowego. Ponadto autor pracy zwraca uwagę, że potrzebne jest opracowanie większej liczby takich sygnałów (zobrazowań) wzorcowych, które mogą być przydatne do monitoringu i diagnostyki obiektów wykonanych z betonu.
[4] Samokrutov A. A., Kozlov V. N., Shevaldykin V. G.: Ultrasonic testing of concrete objects using dry acoustic contact. Methods, instruments and possibilities. The 5th International Conference „Non-Destructive Testing and Technical Diagnostics in Industry". Mashinostroenie, 2006, s.152.

[5] Schabowicz K., Hoła J.: Nondestructive elastic-wave tests of foundation slab in office building, 13th Asia-Pacific Conference on Non-Destructive Testing, Yokohama, Japan, 2009.

[6] Schabowicz K., Hoła J., Styś D.: Nondestructive elastic-wave tests of concrete in founda-tion slab, 10th European Conference on Nondestructive Testing, Moscow, Russia, 2010.

[7] Schabowicz K., Hoła J., Nondestructive elastic-wave tests of foundation slab in office building, Materials Transactions, 53, 2012, s. 296-302. 